Vol. 3, n² | 1999

Varia

\title{
R. Lenoir and J.-J. Yvorel, (eds.) : Michel Foucault. Surveiller et punir : la prison vingt ans après
}

(Sociétés \& Représentations, 1996, 443 p.), ISSN 12622966.

\section{Martin Dinges}

\section{(2) OpenEdition}

\section{Journals}

Electronic version

URL: https://journals.openedition.org/chs/910

DOI: $10.4000 /$ chs. 910

ISSN: $1663-4837$

\section{Publisher}

Librairie Droz

Printed version

Date of publication: 1 June 1999

Number of pages: $114-115$

ISBN: 2-600-00398-3

ISSN: $1422-0857$

\section{Electronic reference}

Martin Dinges, "R. Lenoir and J.-J. Yvorel, (eds.): Michel Foucault. Surveiller et punir : la prison vingt ans après", Crime, Histoire \& Sociétés / Crime, History \& Societies [Online], Vol. 3, n² | 1999, Online since 03 April 2009, connection on 23 March 2022. URL: http://journals.openedition.org/chs/910 ; DOI: https:// doi.org/10.4000/chs.910 
doning and absent mother was cause for considerable anxiety for government authorities ». No supporting evidence from the period is provided for this claim.

Despite Damousi's claim to a new approach in methodology her focus retains a clear binary opposition from the much earlier histories of this period. Although her stated intention is to reinterpret the «cultural meanings » embedded in the texts, the female convicts remain as a collective object within Damousi's investigation. What the reader is invited to participate in is the re-examination of a patriarchal dominant class ideology relative to various aspects of female convict experiences during this period. This reinforces earlier approaches: envisaging female convicts as « victims » - from the illustration on the front cover portraying a provocative and eroticized female from the 20th century to the content of the chapters. Damousi's emphasis on the discourse of authority and her interpretation of the cultural meanings embedded in these texts reinforces a supposition regarding the power of ideology and its accompanying symbolism. Damousi thus fails to show the female convicts as other than how they were described by the dominant class. What Damousi has set out to explore is a very one-sided vision: - the cultural meanings she discloses are not those of the female convicts but those of the various figures of authority. Her definition of play, laughter and sulking as strategies of «resistance» takes no account of these activities having a creative element as response to the crashing boredom prevalent within the walls of incarceration institutions.

To use a culinary image, Depraved and Disorderly resembles a visually appealing dessert - appetising to the eye but lacking substance for the stomach.

Tina Picton Phillipps

University of Edinburgh (U.K.)

9053943@skye.sms.ed.ac.uk

\section{R. Lenoir and J.-J. Yvorel, (eds.): Michel Foucault. Surveiller et punir: la pri- son vingt ans après (Sociétés \& Représentations, 1996, 443 p.), ISSN 12622966.}

In the English speaking world there is no lack of books or collections of essays somehow related to the work of Michel Foucault. One only has to consider the enormous flow of publications on «Gouvernementality " easily accessible in Current Contents. But the publication under review was only possible in France. In accordance with Michel Foucault's own way to do philosophy and politics, this book combines in a very interesting way different approaches to his seminal work about prisons: The book starts with two papers on reading Foucault, written by Bourdieu and Fadat, the latter describing reading experiences with social workers. Some authors remember Michel Foucault as a person, his intellectual development (Castel) or his influence on their proper work (Chauvière), others reconstruct crucial crossroads in the relations between historians and M.F. (Agulhon, Perrot, Petit) or the relation between the judicial world and M.F. (Lenoir), some interpret Foucault's way to do science (Mauger, Yvorel) or show the crucial importance of Rusche and Kirchheimer to M.F. when working out Surveiller et punir (=S\&P) (Lévy and Zander), Lascoumes attempts to develop the notion of «l'illegalisme». Others continue to do research where Foucault had stopped. This is especially true for several articles on confinement and pedagogic attemps to better children in the nineteenth and twentieth century (Bourquin, Pierre, Fillaut, Dupont, Chauvaud, Dekker, 
Ruchat, Fatela). In this case fortunately the documentary limitations to France which characterize the work of M. F. are discarded for a more comparative view including not only the francophone neighbours but also the Netherlands and Portugal. Some of these articles present work in progress, others, like Dekker, sum up earlier work with the intention to enlarge or modify M.F.'s notions. Also, the development of criminology is reconceptualized in terms of episteme (Pasquino) and the discours on criminal women is reconstructed (Koeppel). A section about the actual state of the penal system (Casadamont, Salas, Lazarus, Tournier) brings us back to those practical problems which had been an important incentive to M. F. to work about prisons - and which do not seem to have changed a lot since. But two articles about punishments beyond prison and about forced public work as a punishment go further (Faget, Lazerges). There are also some articles about «Moi, Pierre Rivière » (Peter, Allio, Tsikounas). Several reviews of books which took up Foucault's problematics are added fortunately to the publication.

This collection of different views of the problems treated in «Surveiller et punir» was only possible in a country where Foucault had a certain impact on people working in the administration of prisons. The conference, from which most of the papers were collected, was a meeting of those administrators with some sociologists and several historians and did not even exclude a former minister of justice. Thus, authors from very different horizons met, and this is already a first remarkable effect of this commemoration of a specific intellectual's work. One may imagine that the conference produced a kind of discourse among the different participants which probably led further than the eternal meetings inside specific scientific communities. It seems as if this was one of the main intention of the organizers and editors Rémi Lenoir and Jean-Jacques Yvorel. On the other hand this book is a useful guide to the many directions in which $S \& P$ has become fruitful for further research and political practice. Many of the articles show projects under way and one can attend for the results. As such, the publication is actually the most interesting document about the reception of M.F.'s work in the French speaking community and especially successful in re-activating M.F.'s own way to be a specific intellectual.

\author{
Martin Dinges \\ Institut für Geschichte der Medizin der \\ Robert Bosch Stiftung (Stuttgart, Deutschland) \\ Martin.dinges@po.hi.uni-stuttgart.de
}

\title{
Massimo Meccarelli, Arbitrium. Un aspetto sistematico degli ordinamenti giuridici in età di diritto comune, Milan, A. Giuffrè, 1998, XIII et 394 p., ISBN 88-14-07267.
}

Aujourd'hui que le légicentrisme fait partout fiasco, que la revendication d'un «État de droit», national voire européen, impose partout le magistère et la responsabilité centrale des juges et des juristes, jamais les études portant sur les doctrines juridiques savantes du Moyen Age et du premier âge moderne n'ont été plus instructives. Car du XII ${ }^{\mathrm{e}}$ au XVI $\mathrm{XI}^{\mathrm{e}}$ siècle, la production des normes et la régulation des conduites individuelles et collectives furent principalement tributaires d'un jus comune élaboré à partir des commentaires et des adaptations de la science retrouvée du droit romain. Les théologiens eurent alors beau vitupérer les juristes, à leurs yeux des «idiots politiques», ces idiots n'en ont pas moins acquis longtemps en Occident 